\title{
Operation of subgrades with application of polyurethane binder for its stabilization
}

\author{
Tatiana Barabanova ${ }^{1, *}$ \\ ${ }^{1}$ Moscow State University of Civil Engineering (MGSU), National Research University, 129337, \\ Yaroslavskoe shosse, 26, Moscow, Russia
}

\begin{abstract}
Slopes of road subbase and subgrade under operation are subjected to deformation and destruction while being affected by atmospheric precipitation, deicing agents and temperature drops. Stabilization of road slopes should proceed throughout the entire life cycle of the road. There arose a need to work out the most effective and durable design solution. Structures being under operation are exposed to external factors that cause washouts and defects of expansion joints. Washouts of geocell reinforcement structures may occur as well. Structural repairs sometimes are not effective, so destructions continue and progress. Analysis of the use of conventional technologies has shown that implementation of a polyurethane binder for stabilization of slopes is the most effective design solution under certain conditions. Binder based on polyurethane, when applied to rock material (crushed stone or gravel), forms a durable structure that is resistant to external influences and has high strength properties. A set of national standards for application of this technology is currently being developed. It is confirmed that the material under consideration meets the requirements of fire protection, sanitation and epidemiology, hygiene, and environmental safety. By these days, this technology has been implemented at more than 30 highway structures in the city of Moscow and in the Moscow and Smolensk Regions.
\end{abstract}

\section{Introduction}

To increase the operating life of roads and highway structures and protect subgrades from negative external effects, which include atmospheric precipitates, influence of deicing agents, loads from vehicles, temperature drops, insolation, and vandalism, the improvement of stability of subgrade slopes is required.

Stabilization of subgrade slopes is carried out at all stages of the lifecycle of highways and highway structures, specifically during construction, roadway replacement, road repair and maintenance [1].

Conventional technologies of subgrade stabilization include the following:

- $\quad$ stabilizing with soil and grassing;

- $\quad$ stabilizing with crashed stone or gravel (riprap);

- the use of gabion "Reno" mattresses;

\footnotetext{
* Corresponding author: barabanova.tanya@mail.ru
} 
- the use of three-dimensional geosynthetic structures filled with soil or crashed stone;

- $\quad$ stabilizing with solid or prefabricated reinforced concrete structures.

Consolidated experience of operating subgrades educed several problems. For instance, Figure 1a shows a washout of the slope cone stabilization structure, which exposed the abutment piles. The destruction happened after three heavy rainfalls as a consequence of a defect in the expansion joint. As a result, all the water flows went down from the road surface to the abutment.

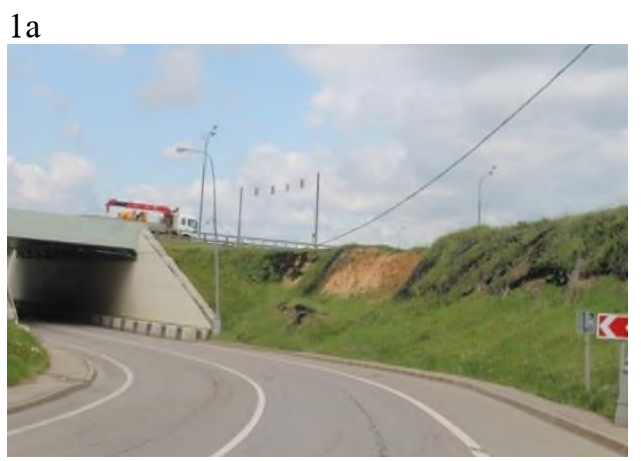

$1 \mathrm{c}$

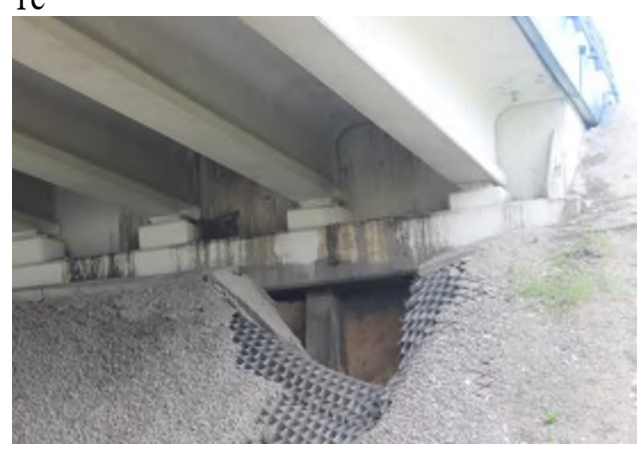

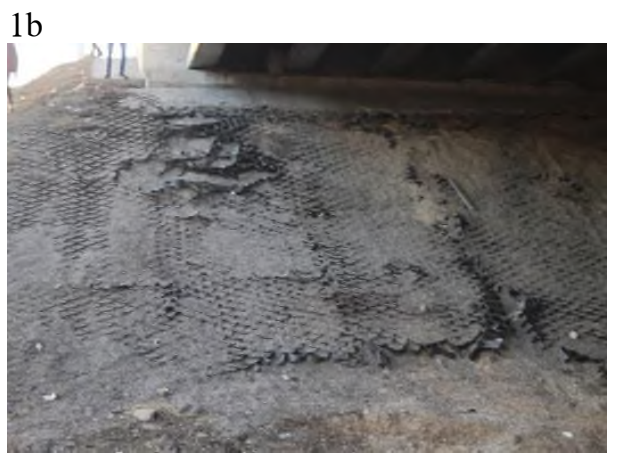

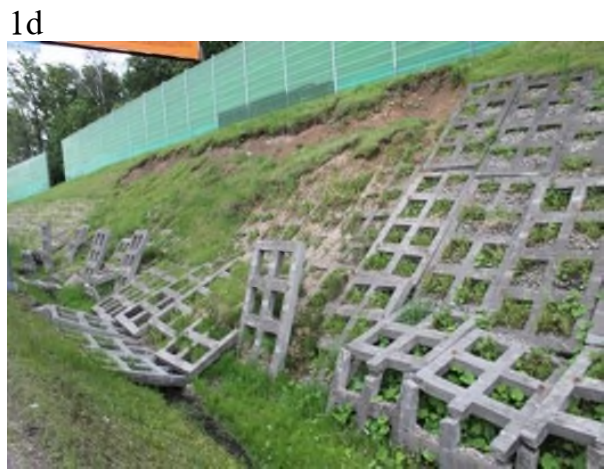

Fig. 1. Defects of slopes stabilized with application of conventional technologies.

Figure 1b shows the cut slopes as parts of a transport junction built more than ten years ago. Defects in the shape of washouts of geocells filled with soil and covered with grassing started appearing during the very first year of operation. The destruction was caused by a large amount of surface and ground water, as well as rough ground conditions. For a decade, the structure has been repaired several times by adding new soil, but these measures were not effective at all, so the destruction continued. It became clear that the structure of subgrade stabilization demanded redesign. The use of crushed stone would also be ineffective for the purpose of subgrade stabilization at this road section, since some stones would crumble down to the roadway under the influence of wind erosion, precipitation and melting snow. If the subgrade was reinforced with concrete, there would arise a problem of groundwater drainage. If using gabions, the problem of vandalism would arise because of the close location of summer cottages. Thus, the use of polyurethane-based binder was chosen as the optimal design solution. 


\section{Methods}

Strengthening slopes with the use of polyurethane-based binder is a technology that bypasses most of the disadvantages of conventional technologies.

Binder based on polyurethane is a system of two liquid components (resin and hardener) which being mixed in a certain ratio and applied to rock material (crushed stone or gravel) form a structure with high strength properties, durability, and resistance to external influences.

The advantages of this way to stabilize slopes are the following:

- $\quad$ high binding strength of the crushed stone layer;

- increased wear resistance of the finished surface;

- $\quad$ simplicity of application;

- $\quad$ presentable appearance of the top layer of processed crushed stone (type of wet stone);

- $\quad$ stability at frequent freezing and thawing;

- $\quad$ resistance to aggressive media;

- non-toxicity;

- fire safety;

- $\quad$ high water permeability of the finished structure.

The development of this technology started as part of a sector-specific policy aimed at widening of the use of composite materials. This policy is reflected in the corresponding programs of the Ministry of Transport, Federal Road Agency Rosavtodor and Russian Highways State Company (Avtodor). The second intended purpose of this technology was to achieve the goals set by the country's authorities to increase the period between highway repairs and roadway replacements. Moreover, within the framework of the state import substitution policy, the production of binder based on polyurethane was launched in the Russian Federation.

\section{Results}

In 2017, Rosavtodor approved the sector-related road guidance document "Methodological recommendations for the use of polyurethane binder for stabilizing slopes, cuts, embankments, cones of bridges and overpasses" [2]. The document contains recommendations on the components of the binder, the structure of stabilization, test methods for determining these parameters, and basic recommendations for the production technology on stabilizing slopes with the use of polyurethane binder.

A set of national standards on application of this technology is currently being worked out. In particular, the project of Federal Standards GOST R "Automobile roads of general use. Technical rules for major repair, repair and maintenance of bridges and culverts" considers the stabilizing of slopes with the use of polyurethane binder as one of technologies to be recommended, along with the use of concrete and gabions.

GOST R “Automobile roads of general use. Polyurethane binder for stabilizing slopes of cuts, embankments, cones of bridges and overpasses. Specifications" contains requirements to materials, such as hardness, elongation per unit length at different temperatures, tensile strength at different temperatures, water absorption, frost resistance, resistance to UV radiation and deicing agents.

To confirm the specified technical requirements, tests were carried out in leading industry laboratories, such as Research Institute of Transportation Construction Complex, Research Institute RosdorNII, Institute of Plastics, Research Institute of the Emergency Control Ministry. 
It was also confirmed that the material meets the requirements of fire protection, sanitation and epidemiology, hygiene, and environmental safety.

The stabilizing structure represents a layer of geotextile (non-woven synthetic material) laid on the leveled subgrade surface. Crushed stone is distributed over the geotextile with or without using three dimensional polymer geocells, after which binder is applied to it. Geotextile layer is needed due to its properties of a reverse filter, which means the ability to pass water, while preventing the penetration of soil particles through the layer. Three dimensional geocells are used to provide the even distribution of gravel and to anchor the structure. At the same time, the use of polyurethane binder allows reducing the height of the geogrid used for stabilizing slopes from $10-20 \mathrm{~cm}$, which is usual for conventional structures, to $7.5 \mathrm{~cm}$. For better water drainage, better cohesion with the filler and for additional adhesive bonds between the cells, perforated geocells are used. Crushed stone or gravel of any dense rocks can be used as a filler. The optimal fraction for use are grains from 20 to $40 \mathrm{~mm}$ in accordance with GOST 8267-93 [3] or fractions from 22.4 to $31.5 \mathrm{~mm}$ in accordance with GOST 32703-2014 [4]. The use of smaller fractions leads to a higher consumption of binder material; the use of larger fractions makes the structure less durable, less even (difficult to go across the structural layer) and less pleasant to eye.

Application of the material in hard-to-reach places is possible both manually and with the use of a special facility. The facility (Figure 2) is equipped with containers for polyurethane binder components, systems for components feeding and mixing, dosing and temperature control systems, and a distribution device. The equipment for applying the material is patented [5].

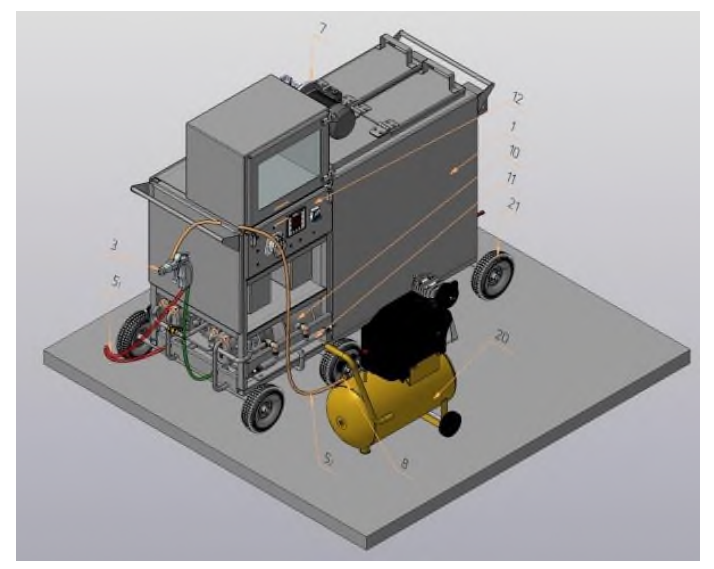

Fig. 2. Isometric scheme of the facility for material application (http://orgsintezresurs.ru).

To prove the effectiveness of the technology for restoring the reinforcement of subgrade slopes of the subgrade and the embankment cones of bridges with the use of a binder based on polyurethane, a comparative calculation of the economic efficiency was carried out over the life cycle of the structure [6].

The work cost is calculated with the help of approved federal unit costs and state elemental estimate standards. Comparison with other options of stabilization shows that stabilizing with polyurethane binder has the minimum operating costs amongst all alternatives, at the same time having lower costs for construction than gabions or concrete structures.

This technology was firstly applied in Russia in 2014 for a part of a subgrade cone of an overpass of Don M-4 road. The state of this structure is constantly monitored, and no defects associated with destruction of the structure have been revealed. 

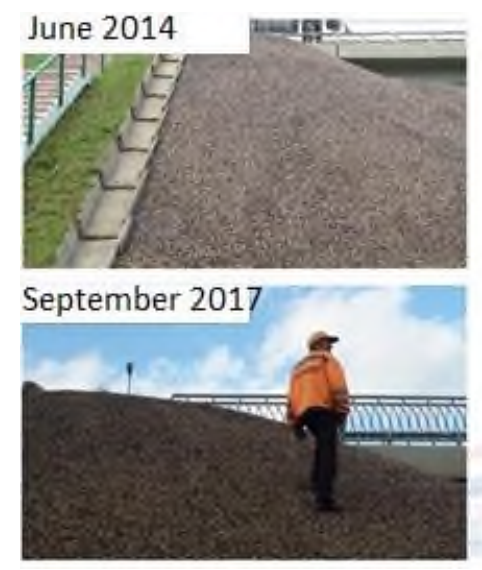
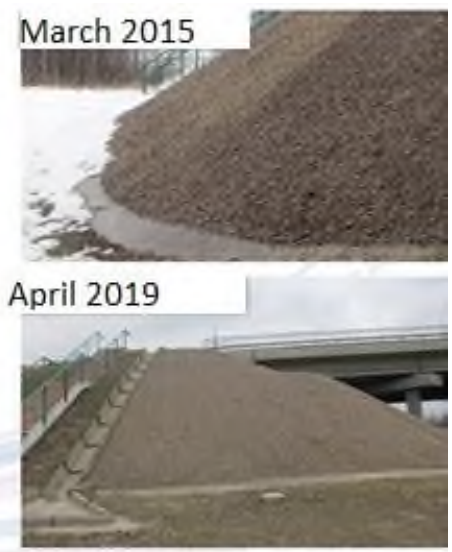

Fig. 3. Structure state monitoring.

Prediction of the service life of the structure was calculated on the basis of the results of laboratory tests with taking into account of the provisions of methodology [7]. Factors influencing the destruction of the stabilization structure over time include the influence of ultraviolet radiation, deicing agents, and temperature changes coupled with the presence of water. Since the structure is not a load-bearing one and does not carry loads from vehicles and pedestrians, these impacts were not taken into account. Laboratory tests have shown $100 \%$ resistance to the effects of deicing agents and ultraviolet radiation, therefore, the key factor for determination of the service life of the structure is its frost resistance. The test on frost resistance consisted in determining the weight loss of samples after repeated cycles of keeping them in sodium sulfate solution, drying in an oven at a temperature of $(110 \pm 5){ }^{\circ} \mathrm{C}$, followed by cooling down to room temperature in accordance with the provisions given in GOST 33109-2014 [8]. According to the results of mathematical processing of the test findings, the average weight loss of the samples was $0.947 \%$ [9].

\section{Discussion}

The tests performed have modeled conditions that are similar for the structure to six years under operation in the city of Moscow (at 70 crossings of $0{ }^{\circ} \mathrm{C}$ ). In order to forecast further wear of the structure, an exponential relationship between the amount of wear expressed in weight loss, and the time of operation is accepted.

Efficiency of the structure is determined by the moment of reaching the permissible wear rate that requires repair work. Its service life is determined by the moment when the wear limit is reached. The allowable wear rate for such structures is $35 \%$, the limit wear rate is $70 \%$. Thus, according to the calculation results it is possible to predict the moment of reaching the permissible wear rate (repair level) for the tested structure, which will come in 31 years after the start of service life. The limit wear rate will be reached by the 56th year after the start of operation, which significantly exceeds the period between repairs prescribed by national standards for highways and highway structures. [10]. 

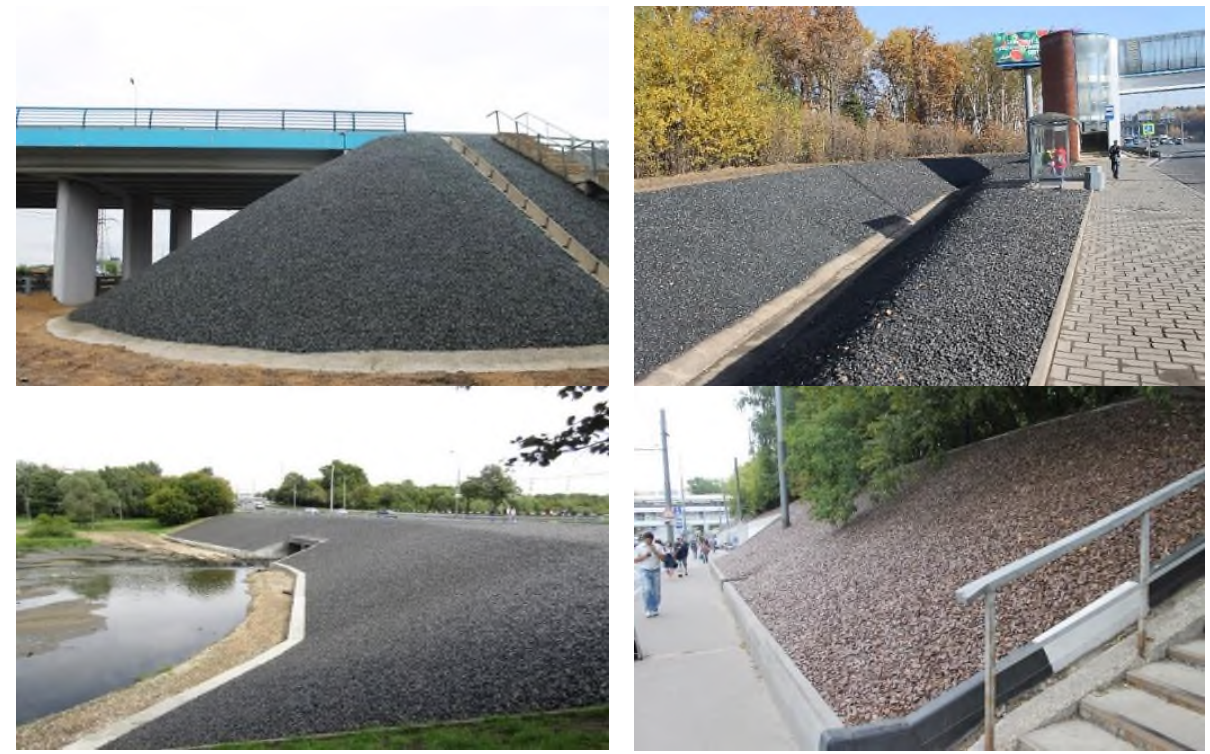

Fig. 4. Pictures of completed objects.

By these days, the technology under consideration has been implemented at more than 30 highway structures in the city of Moscow, in the Moscow and Smolensk Regions (Figure 4). Moreover, this technology is used in landscape design, in stabilization of ballast prisms of railways, in construction of sidewalks and pedestrian paths, and in other areas of construction.

\section{Conclusions}

Consolidated experience in using binder based on polyurethane shows that this technology allows making a structure of high strength properties that is durable and resistant to external influences. This technology has a significant number of advantages over conventional ones: resistance to deicing agents, frost resistance, high wear properties, and minimal operating costs.

\section{References}

1. Klassifikatsiya rabot po kapital'nomu remontu, remontu i soderzhaniyu avtomobil'nykh dorog (approved by order of the Ministry of Transport of the Russian Federation of November 16, $2012 \mathrm{~N}$ 402)

2. ODM 218.3.093-2017. Metodicheskiye rekomendatsii po primeneniyu poliuretanovogo vyazhushchego dlya ukrepleniya otkosov, vyyemok, nasypnykh sooruzheniy, konusov mostov i puteprovodov

3. GOST 8267-93. Crushed stone and gravel of solid rocks for construction works. Specifications

4. GOST 32703-2014 Automobile roads of general use. Crushed stone and gravel from rocks. Technical requirements

5. V.Yu. Leontyev, K.V. Kashtanov, A.V. Kochetkov, Utility model patent № 178405. System for applying two-component reaction mixtures to granular bulk material of 
transport structures, Patent holder is Joint Stock Company "OrgSintezResurs". Application №2018102094

6. Ye.A. Korol', N.S. Nikiforova, Vestnik MGSU 13.3(114), 330-338 (2018)

7. Metodika raschetnogo prognozirovaniya sroka sluzhby zhelezobetonnykh proletnykh stroyeniy avtodorozhnykh mostov (Ministry of Transport of the Russian Federation, 2001)

8. GOST 33109-2014 Automobile roads of general use. Crushed stone and gravel from rocks. Determination of frost resistance

9. V.Y. Leont'yev, K.V. Kashtanov, A.V. Kochetkov, Avtomobil'nyye dorogi 5(1050) (2019)

10. S.N. Stuk, V.A. Potapova, A.A. Domnitskiy, Otchot o nauchno- issledovatel'skoy rabote po teme: "Provedeniye ispytaniy obraztsov shchebnya, obrabotannogo vyazhushchim materialom na osnove poliuretana» (FAU «ROSDORNII», Moskva, 2019) 